San Jose State University

SJSU ScholarWorks

Master's Theses

Master's Theses and Graduate Research

1991

\title{
The correlation between mathematics and reading raw scores and work sample performance of learning handicapped high school students
}

Laraine Domenico-Krapf

San Jose State University

Follow this and additional works at: https://scholarworks.sjsu.edu/etd_theses

\section{Recommended Citation}

Domenico-Krapf, Laraine, "The correlation between mathematics and reading raw scores and work sample performance of learning handicapped high school students" (1991). Master's Theses. 187. DOI: https://doi.org/10.31979/etd.yw9k-zwv5

https://scholarworks.sjsu.edu/etd_theses/187

This Thesis is brought to you for free and open access by the Master's Theses and Graduate Research at SJSU ScholarWorks. It has been accepted for inclusion in Master's Theses by an authorized administrator of SJSU ScholarWorks. For more information, please contact scholarworks@sjsu.edu. 


\section{INFORMATION TO USERS}

This manuscript has been reproduced from the microölm master. UMI films the text directly from the original or copy submitted. Thus, some thesis and dissertation copies are in typewriter face, while others may be from any type of computer printer.

The quality of this reproduction is dependent upon the quality of the copy submitted. Broken or indistinct print, colored or poor quality illustrations and photographs, print bleedthrough, substandard margins, and improper alignment can aưversely affect reproduction.

In the unlikely event that the author did not send UMI a complete manuscript and there are missing pages, these will be noted. Also, if unauthorized copyright material had to be removed, a note will indicate the deletion.

Oversize materials (e.g., maps, drawings, charts) are reproduced by sectioning the original, beginning at the upper left-hand corner and continuing from left to right in equal sections with small overlaps. Each original is also photographed in one exposure and is included in reduced form at the back of the book.

Photographs included in the original manuscript have been reproduced xerographically in this copy. Higher quality 6" $x 9^{\prime \prime}$ black and white photographic prints are available for any photographs or illustrations appearing in this copy for an additional charge. Contact UMI directly to order.

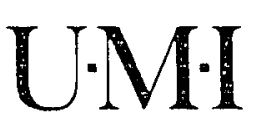

University Microilims International

A Bell \& Howell Information Company

300 Nor th Zeeb Road. Ann Arbor. M1 48106-1346 USA

$313761.4700 \quad 800.521 .0600$ 

Order Number 1945794

The correlation between mathematics and reading raw scores and work sample performance of learning handicapped high school students

Domenico-Krapf, Laraine, M.A.

San Jose State University, 1991

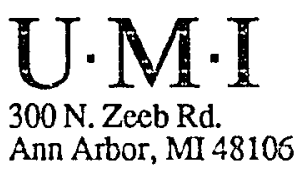





\title{
THE CORRELATION BETWEEN MATHEMATICS AND READING RAW SCORES AND WORK SAMPLE PERFORMANCE OF LEARNING HANDICAPPED HIGH SCHOOL STUDENTS
}

\author{
A Thesis \\ Presented to \\ The Faculty of the Division of \\ Special Education and Rehabilitative Services \\ San Jose State University
}

In Partial Fulfillment

of the Requirements for the Degree

Master of Arts

\author{
By \\ Laraine Domenico-Krapf \\ August, 1991
}


APPROVED FOR THE DIVISION OF SPECIAL EDUCATION AND REHABILITATIVE SERVICES



APPROVED FOR THE UNIVERSITY

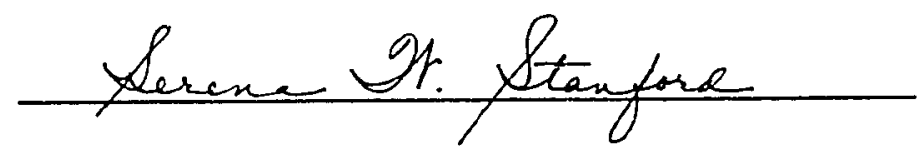




\section{ABSTRACT}

THE CORRELATION BETWEEN MATHEMATICS AND READING RAW SCORES AND WORK SAMPLE PERFORMANCE OF LEARNING HANDICAPPED HIGH SCHOOL STUDENTS

by Laraine Domenico-Krapf

Just as certain jobs require academic skills, this study suggests that the same is true of work samples. If a work sample is measuring a student's ability to perform a general job task, then it would appear that those skills needed to perform the job satisfactorily are also measured through the work sample.

This thesis researched the correlation between performance on the Wide Range Achievement Test-Revised, level 2, and the Gates-MacGinite Reading Test, level D, form i, with each of two work samples. The work samples were Blueprint Reading and Graphics Illustration (MicroTower Rehabilitation \& Research Center, 1978). The purpose was to investigate whether or not there is a significant correlation between reading and arithmetic achievement scores and work sample performance of learning handicapped high school students. 
TABLE OF CONTENTS

CHAPTER

PAGE

I

INTRODUCTION •. • . . . . . . . . . 1

Statement of the Problem . . . . 2

Purpose of the study . . . . . . 3

Assumptions . . . . . . . . . 3

Null Hypothesis . . . . . . . . 4

Limitations . . . . . . . . 5

Delimitations . . . . . . . . 5

Significance of the Study . . . . 5

Definition of Terms . . . . . 6

II

REVIEW OF THE IITERATURE • • • • • • • 9

Summary . . . . . . . . . 15

Instruments Used . . . . . . . . 16

III

METHODOLOGY . . . . . . . . . . 22

Population and Sample. . . . . 22

Rationale of the Design . . . . 23

Plan for Analysis of Data . . . . 25

IV

RESULTS . . . . . . . . . . . 28

Discussion . . . . . . . . 30

Implications . . . . . . . . 32

Future Research . . . . . . . . 34

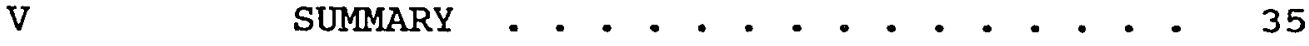

REFERENCES • • • • • . • . • • . • • . . . . 38 


\section{LIST OF TABLES}

TABLE

PAGE

1. Correlations Between Work Sample, Arithmetic, and Reading Scores . . . . . . . . . . . . . 
CHAPTER I

INTRODUCTION

Handicapped individuals face many obstacles in obtaining and maintaining job-related training and employment. They are more frequently unemployed and underemployed than are nonhandicapped individuals (Phelps \& McCarty, 1984). Because of this fact, significant efforts have been made to develop vocational services for handicapped youth, including career and vocational education and evaluation in schools. The California Education Code, Part 30, mandates that "the pupil is assessed in all areas related to the suspected disability including, where appropriate, career and vocational abilities and interests" (Troolin, 1985, p. 12).

Vocational assessment plays a critical role in providing appropriate career programming for handicapped youth by identifying the student's current strengths, weaknesses, and interests (Peterson, 1985). Educators can use this information about the student's natural aptitudes and skills in the career and vocational planning process. Thus, the vocational evaluation can improve the efficacy of individualized program planning for handicapped students in vocational education.

The vocational evaluation process includes the task of providing appropriate recommendations that will guide vocational placement decisions and ensure the student's 
employability. These recommendations may involve specific work-training programs, academic skills improvement, or increased skill in work-related behaviors and characteristics prior to placement in a work-training program. The instruments used to measure the student's skills and aptitude are extremely important.

\section{statement of the Problem}

Approximately $50 \%$ to $70 \%$ of employable handicapped adults are unemployed. If a handicapped person is employed, he is $75 \%$ more likely to be employed part-time than is a nonhandicapped person. More important is the fact that $67 \%$ of unemployed handicapped persons want to work. In appropriate vocational assessment, career counseling, goal setting, transitional planning, work experience programs, and vocational training for youth while in high school have been identified as major barriers for handicapped youth obtaining employment (Hasazi, Gordon, \& Roe, 1985; Rusch \& Phelps, 1987).

While the severely handicapped have a variety of support services (Regional center, center for Independent Living, group homes) providing assistance for both youths and adults, there are limited support services available to people with learning disabilities, especially at the postsecondary level. With only $30 \%$ of the learning disabled employed after high school and only $10 \%$ enrolled in postsecondary educational programs, learning disabled students 
have problems adjusting to adult life (Edgar, 1987). Therefore, learning disabled students must be helped while in high school to ensure employability. Vocational assessment serves as a catalyst for successful career and transitional planning, helps to identify student aptitudes and skills, and forms the basis for appropriate work training programs. Whether learning disabled teenagers, regardless of their academic achievement levels, can successful perform on work samples as part of vocational assessment has not been explored. Research is needed to examine the relationship between achievement in arithmetic or reading and successful completion of work samples in vocational assessment. Purpose of the Study

The purpose of this study was to investigate whether or not there is a significant correlation between reading and arithmetic achievement scores and work sample performance of learning handicapped high school students. Assumptions

The following assumptions were made for the purpose of this research:

1. The students performed the vocational evaluations at the best of their ability.

2. The students used in this research hoped to be gainfully employed at some point in their adult life. 3. The researcher had access to all of the necessary 
records and documents.

4. English-as-a-Second-Language (ESL) students should not have affected the results of this study. If the student's English was limited, an interpreter assisted the examiner during the vocational evaluation. The same procedure was employed with hearing-impaired students.

Null Hypothesis

1. There will be no significant correlation between raw scores of learning handicapped high school students as measured by the Blueprint Reading work sample and the Arithmetic subtest of the wide Range Achievement Test (WRAT) .

2. There will be no significant correlation between raw scores of learning handicapped high school students as measured by the Graphics Illustration work sample and the WRAT Arithmetic subtest.

3. There will be no significant correlation between raw scores of learning handicapped high school students as measured by the Blueprint Reading work sample and the GatesMacGinitie Reading Test.

4. There will be no significant correlation between the raw scores of learning handicapped high school students as measured by the Graphics Illustration work sample and the Gates-MacGinitie Reading Test. 


\section{Limitations}

The following factors may have had an impact upon this research:

1. If the student's attitude toward the vocational evaluation was negative, he may not have applied himself completely.

2. During the vocational evaluation, minimal distractions may have affected a student's concentration.

3. Since the number of students being tested at one time varied, some students may have received more attention, enabling them to achieve more favorable results.

4. Some students may have had reading disabilities, which could have influenced their academic scores. Delimitations

Some of the students who completed the Blueprint Reading work sample also had done the Graphics Illustration work sample at the time of their vocational assessment; therefore, the same students may be a part of the research for Blueprint Reading and Graphics Illustration. Significance of the study

Learning handicapped high school students with low academic skills can succeed in work training programs, providing that a support system exists to enable them to learn vocational material. This study was designed to investigate the importance of these academic skills. students with low reading and arithmetic skills should still 
be able to complete vocational training successfully. If low achievers are able to perform at an average or above level on work samples, the theory that they could succeed in vocational training programs would be supported. Emphasis should then be placed on work sample performance rather than academic abilities during the vocational evaluation process. Definition of Terms

Career education. "The total needs individuals have for community living and working, i.e., avocational, family, citizenship, student, and other important life roles" (Brolin \& Kokaski, 1985, p. 255).

Handicapped students. "Those who have physical, mental, behavioral, or sensory characteristics that differ from the majority of children such that they require special education and related services to develop to their maximum capacity" (Blackhurst \& Berdine, 1981, p. 9).

Learning disabled.

A disorder in one or more of the basic psychological processes involved in understanding or in using language, spoken or written, which may manifest itself in an imperfect ability to listen, think, speak, read, write, spell, or to do mathematical calculations. The term includes such conditions as perceptual handicaps, brain injury, minimal brain dysfunction, dyslexia, and developmental aphasia. The term does not include children who have learning problems which are primarily the result of visual, hearing, or motor handicaps, , or mental retardation, or of environmental, cultural, or economic disadvantage (Blackhurst \& Berdine, 1981, p. 356). 


\section{Psychometric tests.}

Evaluation tools that may investigate achievement, motor skills, and affective variables (interests). These tests are typically norm-referenced, with reliability and validity data available. In some instances, however, criterion-referenced tests are also useful to measure the individual student's level of knowledge of a specific topic. Usually paper-andpencil in nature, psychometrics attempt to correlate test performance with job performance (Phelps \& McCarty, 1984, p. 97).

Reliability. "A test or scale is reliable if it consistently yields the same results when the test is repeated under the same conditions" (Van Dalen, 1979, p. 325) .

Special needs students. Students who have needs that cannot be met by standarà school curriculum (Blackhurst \& Berdine, 1981).

Validity. The characteristic of an appraisal instrument that measures what it claims to measure (Van Dalen, 1979).

Vocational education. Education regarding specific vocations, i.e., education required for the job, hours worked, or job roles.

Vocational evaluation/vocational assessment.

A comprehensive process that systematically utilizes work, real or simulated, as the focal point of assessment and vocational exploration, the purpose of which is to assist individuals in vocational development. Vocational evaluation incorporates medical, psychological, social, vocational, educational, cultural, and economic data in the attainment of the goals of the evaluation process (Peterson, 1985, p. 111). 
Work samples. A comprehensively designed work activity involving tasks, materials, and tools that are identical, or as similar as possible, to those in an actual employment situation. 
CHAPTER II

REVIEW OF THE LITERATURE

It is recommended that both psychometric tests and work samples be utilized in conducting a vocational evaluation (Peterson, 1985; Phelps \& McCarty, 1984; Roberts, Doty, Santleben, \& Tang, 1983). Standardized psychometric tests are norm referenced assessment tools that investigate the student's academic achievement, motor skills, and vocational interests. Usually, test reliability and validity data are available. Administering these tests to students with learning disabilities, however, may present some limitations. Students with learning disabilities are easily distracted, have short attention spans, and become discouraged during lengthy psychometric tests (Wallace \& Larsen, 1978). The reliability of a student's performance under these considerations becomes questionable. Although psychometric tests are necessary for a thorough evaluation, work samples must be incorporated in the evaluation process.

A work sample is an activity involving tasks, materials, and tools that simulates an actual job task or employment situation. The work sample looks like real work and involyes the student directly with a hands-on experience. For example, the Jewish Employment and Vocational Service System developed a work sample called the Union Assembly. The subject is given a box of pipe in 3 and 6 inch lengths, unions, and joints. The subject is then 
given verbal directions, as well as a pictorial diagram of the pipes, joints, and unions assembled. The object of the work sample is to assemble the pieces as quickly as possible to resemble the diagram exactly. Assembling the pipes quickly and accurately shows the student's ability to follow oral directions, understand and follow a diagram, solve a problem, and demonstrate manual dexterity. Students can see how the skills they are using in the work sample directly relate to real work, since they are working with the tools and materials of the trade (Phelps \& McCarty, 1984). Work samples tend to hold the student's interest and motivate the student, which helps to elicit more reliable results. According to Ryan (1986), developing assessment instruments that tap the competencies required by the vocational programs is critical, both in providing for high face validity to maintain student interest in the assessment process and in providing experiences that the student can readily relate to the vocational program or career/job goal they may be contemplating.

Information on learning styles is not directly measured by most psychometric tests. Learning disabled students learn most successfully through their strongest modality (Lerner, 1981) or a multi-modal approach. Work samples allow students to use a visual, tactile, auditory or multisensory approach to complete their task. Work samples also permit a vocational evaluator to observe the style of 
learning students prefer. Independent learners work best with limited contact from teachers and peers. Dependent learners prefer a great deal of contact with teachers and peers. Passive learners prefer quiet, less involved instruction. Active learners work better in a less sedentary situation. Slow-paced learners may need extra time to complete tasks, compared with fast-paced learners. Some students work best when their work is broken into small amounts (Sarkees, 1985).

For the high school student, the vocational evaluation process is both exploratory and preparatory. At the same time that the vocational evaluator is assessing the student with various work samples, the student is indirectly exploring different vocations. The student may find that she enjoys working with her hands. She may find that she is challenged with a task that demands ability to follow a diagram and use problem solving skills or she may be frustrated by a particular task. The student may enjoy working independently or with other people. These insights further support a vocational evaluation that includes work samples as well as psychometric tests.

Tryjankowski (1987) determined that, out of fifteen work samples, only six exhibited ample specificity to warrant the conclusion that a work sample measures a specific trait. Rather, work samples measure a general ability to perform a task and the student's skill in two 
vocational readiness areas: verbal comprehension and perceptual organization. Verbal comprehension is measured since the work sample directions are usually administered orally. Perceptual organization is assessed since the student needs to follow a diagram to complete the work sample successfully. Work samples seem to be able to predict the student's general vocational abilities and some job readiness skills.

Psychometric tests can yield unreliable results regarding the student's academic achievement, interests, and motor skills (Wallace \& Larsen, 1978). Work samples are a more valid measurement of the student's general ability to perform a job task, real or simulated (Tryjankowski, 1987). since it is often assumed that students need a certain level of reading and arithmetic skill to succeed in life and work, the question is whether or not a student with low academic achievement can perform satisfactorily on a work sample. If this same student could obtain job skills in a specific vocational area and be job ready at the time of high school graduation, despite low arithmetic and reading achievement, high school educators could focus on providing their students with specific work training and increased skill in work-related behaviors with less emphasis placed on academic skills improvement.

Basic mathematics and reading skills are important for success in vocational education courses and in work. 
However, the amount of academic skill required varies, depending on the vocational education class or the specific job. For example, construction positions often require measurement skills, while business occupations may require less skill in measurement and more in written communication (Elrod, 1987). The use of academic aids, such as calculators and dictionaries, has also lowered the requirement for proficiency in certain academic areas. Campbell (1986) found that girls take fewer arithmetic courses than do boys. In high school and beyond, the sex differences regarding mathematics achievement and interest are numerous and favor males.

The number of mathematics skills needed to be vocationally successful depends on the job and often can be learned on the job. When one representative from each of 100 occupations in industry was interviewed concerning mathematical competencies, 95\% stated that they used calculators in work-related mathematics problems to save time, as well as to reduce the number of errors. Technicians often work under supervisors who are responsible for the mathematical aspect of the job. There is no empirical evidence that even elementary whole number operations are always essential to satisfactory job performance (Loase, 1983). Every attempt should be made for a student to achieve at his highest potential academically, but, if his highest possible achievement level falls short 
of an employer's expectations, job modifications and academic aids can assist these individuals in being successfully placed in the job market.

In vocational education classes, curriculum modifications can tailor the experiences and activities of the class to meet the unique needs of the individual special needs student. Program standards should not be lowered for special needs students because, if these students are to be employable, they must meet certain proficiency and employability standards. Rather than lower program standards for these students, the following suggestions were made by sarkees (1985): (1) adopt realistic goals; (2) establish a favorable learning environment; (3) determine readability levels for materials used in the program; (4) match learning styles with teaching styles; (5) select appropriate instructional materials; and (6) modify existing materials. These recommendations further lessen the emphasis on academic skills needed to succeed in work training programs and employment.

The ability to get along with others is a skill that transcends all vocational courses (Elrod, 1987). Positive behavior characteristics, such as working continuously, getting to work on time, helping co-workers, following instructions, and asking for help when needed were ranked by employers as the most important skills of a highly valued employee (Salzberg, McConaughy, Lignugaris/Kraft, Agran, \& 
stowitschek, 1987). These characteristics are often weak in handicapped students and adults. If a student with low academic achievement can perform satisfactorily on a work sample, then perhaps employability is more dependent upon learning positive behavior characteristics and appropriate work attitudes than upon increasing academic skills. As society shifts from an industrial society to one of information provision and services, higher education becomes important. Those vocations in higher pay scales will be in technology and information. The educational entry level requirement for these jobs will probably be a minimum of two years of college by the year 2000 (Rice, Farley, \& Parkerson, 1987). If true, this supports the need to develop program modifications and, where appropriate, college goals.

Summary

To summarize, program modifications can be made to aid the success of learning handicapped students in vocational education courses despite lower mathematics and reading abilities. The number of academic skills needed vocationally differs from job to job and can often be learned on the job. Work sample performance tends to be a predictor of general ability to perform job-related tasks, and behavioral characteristics are highly regarded by employers. The vocational evaluation should place emphasis on the student's work sample performance and attitude or 
work behavior, rather than on academic abilities. The object of the vocational evaluation is to acquire enough information about the student's ability and behavior to make vocational planning, placement, and programing decisions. This information is utilized in the student's Individualized Educational Plan. It is used to structure the student's vocational experiences after the vocational assessment, to schedule classes in high school and, where appropriate, to aid adult agencies in assisting students with employment decisions. It is hoped that the vocational evaluation can help the student succeed in vocational education classes by determining the student's strengths and channeling the student into appropriate classes. There is a need to investigate whether low academic achievement levels affect work sample performance since there is a paucity of research addressing this issue.

\section{Instruments Used}

wide Range Achievement Test-Revised (WRAT-R), Ievel 2 . The WRAT-R, Level 2 (Jastak \& Wilkinson, 1984) is for students 12 years and older. It measures reading, spelling, and arithmetic. Only the Arithmetic subtest, consisting of computation problems, was administered. The student is given 10 minutes to complete as many problems as possible. The final raw score yields a grade level, percentile, and standard score.

According to the WRAT-R manual, test-retest reliability 
for the Arithmetic subtest, Level 2, is .79. Concurrent validity correlates the results of the WRAT-R with other achievement and ability tests with results ranging from .60 to .80 . The WRAT-R appears to measure what it was designed to measure, arithmetic computation skill. According to the University of Nebraska-Lincoln (1985), the WRAT-R is appropriate for ages 5 through 64 , grade levels 1.0 to 16.0 , but was not designed for special populations. However, since it measures arithmetic computation skills, it seems suitable for a quick assessment of a student's approximate arithmetic achievement level, whether or not the student is special.

Gates-MacGinitie Reading Test, Level D, Form 1. The Gates-MacGinitie Reading Test (MacGinitie, Kamons, Kowalski, MacGinitie, \& Mackay, 1978) consists of 43 reading passages with two or more comprehension questions per passage. The questions may be literal or inferential. Beginning with passage 1, the subjects read for 35 minutes, completing as many of the 43 passages as possible. The number of questions correctly answered is the raw score which can be converted to a specific grade level for reading comprehension, grade levels range from 2.4 to 12.7 . Approximately 5,000 students per grade participated in the norm group, including a representative proportion of Black and Hispanic students. The Gates-MacGinitie is valid for measuring reading comprehension and reports reliability 
coefficients ranging from .88 to .94 for comprehension, depending on what form is used. Although the GatesMacGinitie Reading Test and the WRAT-R were not designed for special populations, these tests measure the general raw scores for reading comprehension and arithmetic computation of individual students. No test can measure a skill or aptitude with perfect accuracy. Human behavior is too unpredictable, especially that of the special needs student. However, since these are standardized tests, they give a fair rating of academic achievement levels for population. Work samples. The work samples chosen for this research were Blueprint Reading and Graphics Illustration. Both work samples were manufactured by MicroTower Institutional Services in New York (MicroTower Rehabilitation \& Research Center, 1978). MicroTower work samples were field tested in 18 sites around the United states. These sites included a vocationally oriented special education program in a public school, rehabilitation agencies, correctional facilities, and psychiatric hospitals. There are general norms available based on over 1200 people, plus there are percentile norms available for comparison within the following subgroups: Black, Spanishspeaking, left and right handers, physically disabled, psychiatrically disabled, educable mentally retarded, drug abusers, cerebral palsied, brain damaged, and students in special education. The Technical Manual reports a 
reliability coefficient range from .74 to .97 for all MicroTower work samples. The data were based on testretest, alternate forms, and internal consistency estimates. As with any test, the MicroTower work samples give an approximate idea of the student's ability and are more reliable when coupled with other tests measuring the same skills. Work sample performance tends to be a predictor of general ability to perform job-related tasks and assists decision-making regarding a student's vocational training placement recommendations (Botterbusch, 1987).

Blueprint Reading. Work samples are simulated job tasks. Blueprint Reading is primarily a spatial perception task. Those being tested are given a three-dimensional diagram and asked to determine the lengths of various points on the diagram. The illustrations are categorized into a front, end, and top view with distinct measurements noted. The answer sheet shows the same three-dimensional diagram with reference points $a, b, c$, and so on, in place of numerical lengths.

Prior to testing, subjects are given approximately 30 minutes of practice, during which they work with different diagrams. This practice allows sufficient time for the student to fully understand the concept and the exact type of measurements they will be asked to perform on the test. Extra practice time is allowed when needed. The student is then asked to determine the specific length 
of $a, b, c$, and others and note their answers on the answer sheet.

The raw score consists of the number of correct answers out of 24 possible. The student is given 15 minutes to take the test and the vast majority of those being tested finish within the time allowed. All of the students who were a part of this research finished within the allotted time. Although speed was not stressed, the students were aware of the time limit during testing. This did not seem to interfere with their performance.

Graphics Illustration. This work sample also assesses spatial perception but includes more problem solving. It involves manual and finger dexterity and motor coordination. The practice period provides instruction in the use of four drafting tools: straight edge, T-square, and compass. The student is given as much time as needed to master the use of these tools by copying three sets of graphic designs. Enough practice time is allowed to ensure that the student fully understands the concepts needed and to practice the exact type of designs they will be asked to complete on the test. The test portion of Graphics Illustration requires the use of drafting tools to complete four increasingly complex designs. The student is given 45 minutes to complete the four designs and the vast majority finish well within that time (Botterbusch, 1987). 
Scoring is accomplished by using template overlays. The raw score is based on the correct number of lines drawn, those drawn with the specified tolerance. The maximum possible score is 32 .

The followi.ng information should serve as a reference guide for work sample raw scores. When a national sample of 1,219 rehabilitation clients serve as the norm group, a raw score of 31 to 32 is equal to approximately the 81 st percentile and above for the Graphics Illustration work sample. An average raw score would be approximately 23 to 26, resulting in the 41 st to 60 th percentile. A raw score of 14 is equal to the 20 th percentile. For the Blueprint Reading work sample, using the same norm group, a raw score of 24 is equal to the 81st percentile and above. A raw score of 19 or 20 equals the 41 st to 60 th percentile, while a raw score of 11 is equal to approximately the 20th percentile. 
CHAPTER III

METHODOLOGY

\section{Population and Sample}

The subjects of this research were drawn from a high school population within a unified school district in the Bay Area. The district served 200,000 citizens living within 110 square miles including $37.18 \%$ Black, 33.49\% White, 13.18\% Hispanic, 10.95\% Asian and Pacific American, $4.77 \%$ Filipino, and .43\% Alaskan and Native American. The district facilities included 37 elementary schools, 4 junior high schools, 1 middle school, 5 senior high schools, 1 continuation high school, 1 career development center, and 1 post-secondary adult education school. Total enrollment in the district was 28,378 in 1987 and 29,593 in 1988 .

The subjects of this research were 45 special education students 14 to 19 years of age who had a formal vocational evaluation. Any student in the special education program in the district had the opportunity for a vocational evaluation. They were most often referred by their special education teacher, the teacher responsible for their Individualized Educational Plan. Since the evaluation process is very structured and demanding, it is more appropriate for some special education students than for others. Those who are not best served by this assessment receive vocational assessment on a job site or a less formal assessment given by their special education teacher. Those 
students who were a part of this research were learning handicapped students enrolled in a special day class or resource specialist program, or students who were communicatively handicapped, visually impaired, or hearing impaired.

The ethnic and gender composition of the students involved in this research was as follows: $75.5 \%$ male, $24.5 \%$ female, $40.0 \%$ Black, $42.2 \%$ White, $8.9 \%$ Asian and Pacific American, $6.7 \%$ Hispanic, and 2.2\% Alaskan and Native American. There was a total of 45 students from 5 different high schools, 1 continuation high school, and 1 community college. They were specifically represented as follows: $37.8 \%$ High School 1, 20.0\% High School 2, 13.3\% High School 3, 11.1\% High School 4, 8.9\% High School 5, 4.4\% Continuation High School, and $4.4 \%$ Community College. Rationale of the Design

In order to ascertain the magnitude of the relationship between mathematics and reading achievement levels and work sample performance, the Pearson product-moment correlation (r) method of statistical analysis was used. This technique allows one to determine the direction and degree of relationship by plotting the test score $(x)$ and the student's raw score $(y)$ on a graph. The magnitude of the correlation depends on the extent to which an increase or decrease in one variable $(x)$ is accompanied by an increase or decrease in the other $(y)$. A perfect positive 
correlation exists if the subject scores high on both

variables or low on both variables. These scores would fall in a straight line, or linear distribution, creating a visual picture that allows one to discern the direction and degree of the relationship (Van Dalen, 1979).

The particular method of design chosen for this study was ex post facto in nature. According to Van Dalen (1979):

Ex post facto research lacks the control inherent to experimental research. The consequence of this weakness is the risk of improperly interpreting results because of the possibility of many explanations and it often does not produce the precise reliable knowledge that can be gained through rigorous experimental studies. However, it does provide the ability to identify clues to problems that cannot be dealt with in laboratory situations. It is, therefore, necessary to treat the results and interpretations of this research with caution. (p. 310)

While the students who participate in vocational assessment may have more than 14 work samples to choose from, it was impossible to include all of them for this research. The two samples included were chosen because of their ability to fit into the pearson product-moment correlation method of statistical significance. other statistical formulas will be needed to research the other work samples on a comparative basis. Of the 45 subjects who participated in this research, 45 completed the Blueprint Reading work sample and 29 completed Graphics Illustration. Both of the work samples were completed by $64 \%$ of the subjects, while $36 \%$ completed one of the two. 


\section{Plan for Analysis of Data}

The researcher reviewed files of all students who had a vocational evaluation and who enrolled in work training programs at the Career Development Center during the 1987-88 or the 1988-89 school year. Only those students who had taken the Blueprint Reading work sample and/or the Graphics Illustration work sample were included for this research. Since all students who had a vocational education had taken the Gates-MacGinitie Reading Comprehension test and the WRAT-R Arithmetic subtest, all files contained academic achievement information.

The Pearson product-moment correlation, designated $\underline{r}$, can be computed in several ways. The particular method used for this research involved a two-dimensional frequency table with the distributions of the raw scores of both tests labeled and grouped into specific intervals. In order to perform mathematical calculations, the steps for this method involved preparing a two-dimensional frequency table with each distribution, $\mathrm{x}$ and $\mathrm{y}$, grouped into 10 to 15 class intervals (Van Dalen, 1979). On the Gates-MacGinitie Reading Test, raw scores can range from 1 to 43 . Since no student scored above 40 , the range used was 1 to 40 . The scores were then grouped to result in 10 cells, i.e., 1-4, 5-8, - - 37-40. For the WRAT-R, Level 2, Arithmetic raw scores range from 1 to 66. However, the student scores in this study ranged from 12 to 41 . Therefore, these scores 
were grouped by 3 so they would form 10 cells, i.e., 12-14, 15-17, 18-20. The Blueprint Reading work sample scores range from 1 to 24 . Although there were no student scores below 9 in this study, scores 1 to 8 were included in cells so that the two-dimensional frequency table would result in at least 10 cells. For the Graphics Illustration work sample, scores extend from 1 to 32 . Although there were no student scores below 10 in this study, scores 3 to 9 were included so that the two-dimensional frequency table would have a minimum of 10 cells. Emphasis was placed on the general distribution of scores.

A tally mark was placed in the proper cell in the frequency table for each raw score on the designated work sample. The y distribution represented academic raw scores. For example, if the student scored 23 on the work sample test and 10 on the Gates-MacGinitie Reading Test, a tally mark was placed in the cell where the 23 and the 10 columns intersect (see page 27). The scores were tabulated by $y$ variable (academic raw score) and $x$ variable (work sample raw score).

High performance students were those whose work sample raw scores fell in the last two cells on the right side of the two-dimensional frequency table, $x$ variable. Conversely, low performance students were those whose work sample raw scores fell in the first 5 to 6 cells on the left side of the table, scores 1 to 12 for Blueprint Reading and 
$\mathrm{X}=$ Work Sample Raw Score

\begin{tabular}{|c|c|c|c|c|c|c|c|c|c|c|c|c|}
\hline & $\begin{array}{l}1- \\
2 \\
\end{array}$ & $\begin{array}{l}3- \\
4 \\
\end{array}$ & $\begin{array}{l}5- \\
6 \\
\end{array}$ & $\begin{array}{l}7- \\
8 \\
\end{array}$ & $\begin{array}{l}9- \\
10 \\
\end{array}$ & $\begin{array}{l}11- \\
12\end{array}$ & $\begin{array}{l}13- \\
14 \\
\end{array}$ & $\begin{array}{l}15- \\
16 \\
\end{array}$ & $\begin{array}{l}17- \\
18 \\
\end{array}$ & $\begin{array}{l}19- \\
20 \\
\end{array}$ & $\begin{array}{l}21- \\
22 \\
\end{array}$ & $\begin{array}{l}23- \\
24 \\
\end{array}$ \\
\hline - 29-32 & & & & & & & & & & & & \\
\hline $\begin{array}{l}0 \\
\text { is } 25-28 \\
\end{array}$ & & & & & & & & & & & & \\
\hline 离 $21-24$ & & & & & & & & & & & & \\
\hline G $17-20$ & & & & & & & & & & & & \\
\hline $13-16$ & & & & & & & & & & & & \\
\hline \& & & & & & & & & & & & & 1 \\
\hline " $\quad 5-8$ & & & & & & & & & & & & \\
\hline$>-1-4$ & & & & & & & & & & & & \\
\hline
\end{tabular}

$1=$ tallies

scores 3 to 17 for the Graphics Illustration work sample.

High academic achievement students were those whose academic raw scores, Reading and Arithmetic, fell in the top 3 cells at the $y$ variable, scores 33 to 41 for arithmetic computation and 29 to 40 for reading comprehension. Conversely, low academic achievement student scores fell in the bottom 4 cells at the $y$ variable. This would equal scores ranging from 12 to 23 for arithmetic computation and 1 to 16 for reading comprehension. Standard deviations, means, and correlation coefficients were then determined. 


\section{CHAPTER IV}

\section{RESULTS}

The students who were a part of this research were learning handicapped students enrolled in a special day class or resource specialist program, or students who were communicatively handicapped, visually impaired, or hearing impaired. They were 14 to 19 years of age and had participated in a formal vocational evaluation. It was expected that students with low academic achievement levels would perform as well as students with high academic achievement levels on work sample tests. Since academic aptitude is often just one aspect of some forms of work, it was expected that those students with low academic skills would perform as well as students with high academic skills on most work samples.

As shown in Table 1, there was a significant correlation between the Blueprint Reading work sample raw score and the WRAT-R Arithmetic raw score. The Blueprint Reading raw score mean was 19.2 with a standard deviation of 4.6. The mean WRAT-R Arithmetic raw score was 24.3 with a standard deviation of 5.2. Therefore, Null Hypothesis 1 was rejected $(\underline{r}=.64)$. High academic skill in Arithmetic did appear to be necessary for a student to perform well on the Blueprint Reading work sample.

As shown in Table 1, there was no significant correlation between the Graphics Illustration work sample 
Table 1

Correlations Between Work Sample, Arithmetic, and Reading Scores

\begin{tabular}{lcccc}
\hline Test & N & $\overline{\mathrm{X}}$ & SD & $\underline{x}$ \\
\hline Blueprint Reading & 45 & 19.2 & 4.6 & .64 \\
WRAP-R Arithmetic & 45 & 24.3 & 9.0 & \\
Graphics Illustration & 29 & 25.6 & 5.6 & .01 \\
WRAT-R Arithmetic & 29 & 28.0 & 5.5 & \\
Blueprint Reading & 45 & 19.2 & 4.6 & .89 \\
Gates-MacGinitie Reading & 45 & 16.8 & 9.0 & \\
Graphics Illustration & 29 & 25.6 & 5.6 & 8.4 \\
Gates-MacGinitie Reading & 29 & 18.6 & & \\
\hline
\end{tabular}

raw score and the WRAT-R Arithmetic raw score. The Graphics Illustration raw score mean was 25.6 with a standard deviation of 5.6. The mean Arithmetic raw score was 28.0 with a standard deviation of 5.5. Therefore, Null Hypothesis 2 was not rejected. High academic performance in arithmetic was not necessary for the student to perform well on the Graphics Illustration work sample $(\underline{r}=.01)$. As shown in Table 1, there was a significant correlation between the Blueprint Reading work sample raw score and the Gates-MacGinitie Reading raw score. The 
Blueprint Reading raw score mean was 19.2 with a standard deviation of 4.6 . The mean reading raw score was 16.8 with a standard deviation of 9.0. Therefore, Null Hypothesis 3 was rejected. High academic skill in reading appeared to be necessary for a student to perform well on the Blueprint Reading work sample $(\underline{\underline{r}}=.89)$.

As shown in Table 1, there was no relationship between the Graphics Illustration work sample raw score and the Gates-MacGinitie Reading raw score. The Graphics Illustration raw score mean was 25.6 with a standard deviation of 5.6. The mean Reading raw score was 18.6 with a standard deviation of 8.4. Therefore, Null Hypothesis 4 was not rejected. High academic performance in reading was not necessary for a student to perform well on the Graphics Illustration work sample $(\underline{r}=.06)$.

Discussion

Since the student population in this study is unique because the data are derived from one specialized vocational program in one district, the results may not be characteristic of other districts. The use of caution is necessary in the formulation of broad generalizations. The results of this study suggest that academic achievement may affect work sample performance on some work samples. Although the directions are oral, the Blueprint Reading work sample does require an understanding of mathematical measurement, the ability to read questions, and 
the ability to mark answers on a separate answer sheet. Although the reading is minimal, it would appear that academic ability influences the student's performance on the Blueprint Reading work sample. The Graphics Illustration Work sample has oral direction also, after which the student duplicates specific designs. There is no independent reading for the student, nor are there any mathematical measurements. The Graphics Illustration work sample utilizes problem solving skills in an artistic manner and requires the use of drafting tools, T-square, compass, and ruler. Manual and finger dexterity, motor coordination, and spatial perception would appear to be important skills necessary to successful completion of this work sample. Just as certain jobs require academic skills, this study suggests that the same is true of work samples. If a work sample is measuring a student's ability to perform a general job task, then it would appear that those skills needed to perform the jou satisfactorily are also measured through the work sample. Even though the mean arithmetic and reading raw scores for Graphics Illustration were higher than for Blueprint Reading, it would appear that Blueprint Reading may be a vocation for those individuals with higher academic skills. It is also possible that the Vocational Evaluator accidentally chose students with higher academic performance scores to complete the Graphics Illustration work sample, thereby increasing the mean raw scores in the 
academic achievement areas for that work sample.

With both work samples, the mean raw score for arithmetic is higher than is the mean raw score for reading. This score may have been influenced by the large percentage of male students involved in this research. Girls take fewer arithmetic courses than do boys and are more often found in introductory and lower level courses than in advanced courses. In high school and beyond, the sex differences found in arithmetic are many and favor males (Campbell, 1986).

If a majority of the students in this research had disabilities in reading, this may also have influenced the mean raw scores in academics. This study did not separate students according to specific disabilities.

\section{Implications}

Every effort should be made for a student to achieve his potential academically. For those unable to compete in higher education, vocational training becomes very important while in high school. A marketable skill is acquired to support oneself after high school, or a skill is learned that can be improved upon while in college. Even if a student plans to continue with higher education, a particular skill may be imperative to his economic survival while he pursues a higher education. A student must never be underestimated and a vocational evaluation must never assume. If the student expresses interest in a particular 
vocation, that vocation should be explored through work samples, job shadowing, or job tryout.

Another implication from this research is that job modification and accommodations need to be provided for the handicapped in the work place. If a student is having difficulty with a work sample, the vocational evaluator should discern what changes could aid him in successfully completing his task. It is important that a professional assist the student with any necessary modifications and accommodations and that follow-up be provided for the student after job placement is made.

Skills that seem to make an employee a valuable worker center around work behaviors and attitudes. As more handicapped people secure and retain jobs, the focus must shift to assisting the handicapped to become workers who are highly valued by their employers because they possess desired work behaviors and attitudes. A positive disposition and good work behaviors, such as arriving at work on time and working at or above expected rates, are directly related to job productivity (Salzberg et al., 1987). It then becomes critical that educators concentrate on improving work attitudes and behaviors for the special needs student. This emphasis should begin as early as preschool when career exploration and daily living skills are addressed. For the learning handicapped student, this is a time when the foundation is laid for later vocational 
education. If a positive attitude is formed at an early age, and a correlation is made between academics and careers, then perhaps the learning handicapped student will understand the importance of his education and his future.

\section{Future Research}

Further research could be conducted relating academic performance to mechanical, food service, and technologybased work samples. Perhaps it would be useful to compare male and female work sample performance to academic achievement levels or to compare specific disabilities, work sample performance, and academic achievement.

The ability of vocational evaluation to predict student success in vocational education courses, such as Regional Occupational Program (R.O.P.) or job placement, is worthy of further investigation.

Vocational evaluation, vocational education, and transition services all seem to be important in improving the quality of life for the special needs student. Further research in these areas would provide educators with concrete facts on which to base the education plans for their students. 


\section{CHAPTER V}

\section{SUMMARY}

The academic achievement levels of 14- to 19-year-old learning handicapped high school students were compared to their performance on one of two MicroTower work samples, Blueprint Reading and Graphics Illustration. The GatesMacGinitie Reading Test and the wide Range Achievement TestRevised (WRAT-R), Arithmetic subtest, were used to measure academic achievement. The purpose of the study was to determine whether or not there was a significant correlation between reading and arithmetic achievement levels and work sample performance as computed by the Pearson product-moment correlation coefficient method, designated $\underline{\underline{r}}$.

High academic performance in reading and arithmetic was not necessary for a student to perform well on the Graphics Illustration work sample. There was a marked relationship between the Blueprint Reading work sample performance and the student's arithmetic and reading achievement levels. Results indicated stat academic achievement may affect the student's performance on some work samples. Even though a hands-on task stimulated these students into working harder and applying themselves more fully, that factor alone was insufficient for them to achieve success. Just as certain vocations require academic skills, this study suggests that the same is true for some work samples. Those work samples requiring academic skills may be more difficult for students 
with low academic performance levels. An evaluator should, therefore, be aware of which work samples do and do not have an academic component or skill required.

Further results showed that the mean grade levels were higher for arithmetic on both work samples. Students tended to score just as well on the Graphics Illustration work sample as they did on the Blueprint Reading work sample. According to Ryan (1986), developing vocational assessment instruments that tap the competencies required by the vocational programs is critical both in providing face validity to maintain student interest in the assessment process and in providing experiences that the student can readily relate to the vocational program or career/job goal they may be contemplating.

It is theorized that a vocation exists for all individuals, that even the most severely handicapped student can achieve high self-esteem and a sense of contributing to society through some form of work, paid or volunteer. While this still may be true, there is evidence that low academic skill may impede a student's ability to succeed on those work samples that require competency in academics. For students who peak academically, there still needs to be options and work samples that help place them; however, the stimulation and motivation provided by a work sample is not enough to ensure student success in completion of work samples that have an academic component. Every effort must 
be made for the student to achieve at his highest academic potential because higher paying jobs of the future will probably require a minimum of two years of college at the entry level. Once acceptable academic skill levels are achieved, then work samples will identify skills that need improvement, pinpoint the most effective instructional methods, help determine specific services, and predict one's ability to perform a general job task successfully. 
REFERENCES 
Blackhurst, A., \& Berdine. W. (1981). An introduction to special education. Canada: Little, Brown \& Co.

Botterbusch, K. (1987). A comparison of computerized job matching systems (2nd ed.). Wisconsin: School of Education and Human Services University of Wisconsinstout.

Brolin, D. \& Kokaski, C. (1985, April)。 Enhancing transition from school to the workplace for handicapped youth: The role of special education. Paper presented at a conference sponsored by The National Network for Professional Development in Vocational Special Education, University of Illinois, Anaheim, CA.

Campbell, P. (1986). What's a nice girl like you doing in a math class? Phi Delta Kappan, March, 516-519.

Edgar, E. (1987). Secondary programs in special education: Are many of them justifiable? Exceptional Children, 53, 555-561.

Elrod, G. (1987). Academic and social skills pre-requisite to success in vocational training: Perceptions of vocational educators. The Journal, Fall, 17-21.

Hasazi, S., Gordon, L., \& Roe, C. (1985). Factors associated with the employment status of handicapped youth exiting high school from 1979 to 1983. Exceptional Children, 51, 455-468.

Jastak, S., \& Wilkinson, G. (1984). Wide Range Achievement Test: Administration manual. Wilmington, DE: Jastak Associates, Inc.

Lerner, J. (1981). Learning disabilities (5th ed.). Boston, MA: Houghton Mifflin Co.

Loase, J. (1983). Math training for today's job market. Curriculum Review, MaY, 165-168.

MacGinitie, W., Kamons, R., Kowalski, R., MacGinitie, R., \& Mackay, T. (1978). Gates-MacGinitie reading tests, level $D$, forms $1,2, \& 3$ : Teacher's manual. NY: The Riverside Publishing Co.

MicroTower Rehabilitation \& Research Center. (1978). MicroTower ICD. New York, NY: Institutional Services Research Center. 
Peterson, M. (1985). Models of vocational assessment of handicapped students. Career Development for Exceptional Individuals, Fall, 111-119.

Phelps, A., \& McCarty, T. (1984). Student assessment practices. Career Development for Exceptional Individuals, Spring, 31-39.

Rice, B., Farley, R., \& Parkerson, S. (1987). The future workplace: Implications for vocational evaluation. Vocational Evaluation and Work Adjustment Bulletin, Fall, $\underline{20}(3), 95-98$.

Roberts, S., Doty, D., Santleben, S., \& Tang, T. (1983) . A model for vocational assessment of handicapped students. Career Development for Exceptional Children, Fall, 101110.

Rusch, F., \& Phelps, L. (1987). Secondary special education and transition from school to work: A national priority. The Council for Exceptional Children, 53(6), 487-492.

Ryan, D. (1986). A practitioner's point of view: Curriculum based work samples: Applications in the vocational evaluation of special needs students. Vocational Evaluation and Work Adjustment Bulletin, Spring, 5-8.

Salzberg, C., McConaughy, E., Lignugaris/Kraft, B., Agran, M., Q Stowitschek, J. (1987). Behaviors of distinction: The transition from acceptable to highly-valued worker. The Journal, Fall, 23-28.

Sarkees, M. (1985). Vocational special needs. Homewood: IL: American Technical Pübishers, Inc.

Troolin, B. (1985). Minnesota transition resource manual. White Bear Lake, MN: Minnesota Curriculum Services Center, pp. 12-20.

Tryjankowski, E. (1987). Convergent-discriminant validity of the jewish employment and vocational service system. Journal of Learning Disabilities, 20(7), 433-435.

University of Nebraska-Lincoln, Buros Institute of Mental Measurements. (1985). The ninth mental measurement yearbook, I \& II, pp. 1734-1735\&597.

Van Dalen, D. (1979) . Understanding educational research. New York: McGraw-Hill, Inc. 
Wallace, G., \& Larsen, S. (1978). Educational assessment of learning problems: Testing for teaching. Boston, MA: Allyn \& Bacon, Inc. 